This book may be said to bring the whole controversy up to date, although the bias is strongly on the unionist side and with it the rejection of the Columbian theory. The concept is not that yaws and syphilis are the same disease, but rather that they are different manifestations of treponematosis, or the effects of $T$. pallidum. It is argued that this organism, almost as old as Man himself, probably came out of Africa in the early migrations, and that this main reservoir has ever since been responsible for its flow to the different corners of the globe. The disease as it affected the African was of the yaws type ; it was and still is spread by close contact and flies, under bad social conditions. Making use of the moist skin surfaces of humid climes, it is, therefore, able easily to take root in a fresh host and therefore is primarily a disease of childhood. Being a disease of the young, the girl by the time she becomes a mother is no longer infectious and hence congenital forms are rare. Without treatment and allowed to run its full course, the disease has skin and bone lesions predominant in the tertiary stage, and occasional severe mutilations such as gangosa; but neurological or cardiovascular involvement is rare.

As the centuries advanced, social conditions changed. The negro taken in slavery no longer was subject to the same climatic and hygienic conditions, and the white man contracting the disease was able to do so only by sexual intercourse with the infected. Thus the stage became set for the juvenile forms to decline and venereal types, with the increased risk of congenital transmission, to increase. The spirochæte, no longer able to propagate its species into a fresh host, had to rely on promiscuous sexual intercourse as virtually the only means left for survival. The warm, moist skin, still prevailing at mucocutaneous junctions and certain skin sites, showed in miniature what formerly prevailed all over the body. What is more, once the organism had taken hold it was subject to all sorts of drastic medicines, inunctions, and injections; and therefore in time the strain became toughened and likely, therefore, in animal experiments, to show certain differences between that of a strain taken from a primitive native.

This change from a juvenile contact spread of the disease to the adult venereal form was not sudden and there were transitional forms. We have areas in the world even today where the disease is an accidental infection of children, but climatic conditions have forced upon it a greater likeness to venereal syphilis. Examples of this are : bejel, pinta, and irkintja (Australian boomerang leg). History also affords instances where the venereal form has, with suitable climatic or social conditions, reverted to the primitive type. For example there is sibbens, a disease of the Highlands of Scotland at the time of the Civil war, radesyge in Scandinavia in 1700, skerlljeyo in the Balkans at the end of the eighteenth century, and certain manifestations of juvenile syphilis seen in Southern Russia in the nineteenth century, and even occasionally still found today.

This, then, is the argument. To it is added the acceptance that yaws is a very ancient disease which has always been present in the Old World, but, as it was mainly of the juvenile form, it did not find a place in ancient literature as a sexual disease. When the disease became venereal it was confused with leprosy. It is scattered all over Europe, and later America, primarily by the slaves; and the white man always caught yaws, never syphilis, from the African. It was probably present in very early times in the Western hemisphere but there is no evidence that the natives of Haiti actually suffered from it before the arrival of Columbus. It is therefore suggested that one or more of Columbus' men may have been infected before leaving Europe and that subsequently the more courageous of the local natives became infected, in turn infecting others, and thus, in consequence, the Indies were given the blame ; a pretence eagerly maintained by the Church.

This book is recommended to all those who have not yet studied this absorbing subject. For the great number who have, it is a new, sober, entertaining, and constructive book which attempts, perhaps only too successfully, to explain all the differences of opinion which have existed between the two sides.

(It may be churlish, when this book has been found so enjoyable, to point out that Prince Henry of Portugal did not reach the equator in 1470, as he had died over ten years before.) R.R.W.

\section{HANDBOOK OF DIAGNOSIS AND TREATMENT OF VENEREAL DISEASES}

By A. E. W. McLachlan, M.B., Ch.B. (Ed.), D.P.H., F.R.S.Ed.

(Edinburgh: E. and S. Livingstone. 1947. Third Edit. Pp. 375. Illustrated. Price 15s, net.)

The appearance since 1944 of three editions of McLachlan's Handbook of Venereal Diseases is almost an adequate testimony of its usefulness and popularity. The third edition, which now comprises 375 pages, has received few expansions or additions in text or illustrations. The latter. which maintain effectively the high standard achieved in previous editions, portray judiciously selected studies, twenty in colour, of the more common venereal conditions.

The text on the treatment of syphilis has the advantage of not being relegated to a separate, and sometimes remote chapter, as it has been in some books on this subject, but follows hard on the descriptive matter of each of the various stages of the disease-an arrangement which will be appreciated by the student while the clinical aspects are fresh in his mind.

The gradual accumulation of data on the use and results of penicillin therapy in early syphilis during the last two years has led to some expansion of the text. The amount of penicillin considered to have been possibly adequate in 1945 (2.4 mega units in $7 \frac{1}{3}$ days) and advocated in the previous edition, has now been increased in amount to from 7.5 to 10 mega units in 15 days; and, in addition, treatment with arsenicals and bismuth is recommended, as it now is by most authorities. 
Four alternative schedules of treatment with arsenicals and bismuth are advocated, including an intensive twenty-day course for in patients. In advising the use of intensive arsenical therapy more stress should be laid on the high incidence of the toxic effects of arsenic, which are an unwelcome and important accompaniment.

Arsenical dermatitis and other arsenical toxic effects are well described and illustrated, but in the section on their treatment there is no mention of the use of BAL (di-mercaptopropanol) which has recently superseded all other remedies.

The lesions and pathology of the various stages of syphilis are lucidly described, as also is the Wassermann reaction and its clinical interpretation, The use of the so-called ' provocative 'Wassermann reaction is still advocated although, surely, most authorities have lost faith in this procedure, more especially since a similar 'provocative' effect was demonstrated in non-syphilitic persons by Barnett and others in 1938.

The instructions on the use of bismuth in early syphilis are given in full practical detail but are somewhat marred by the plethora of compounds listed-sixteen in all-without any clear indication of which preparations are favoured or used by the author.

The instructional value of the Handbook, in general, is high, although the text is necessarily compressed. In particular the chapters on congenital syphilis, on vulvovaginitis, and on gonococcal infections of the eye are noteworthy.

The inclusion in future editions of a summary of the present-day public health anti-venereal measures and a brief account of their aims and results would no doubt be welcome to the post-war student, who in many instances is an ex-serviceman with some interest in and knowledge of hygiene.

The Handbook will doubtless retain its position as the most useful small book on this subject for the medical student.

V.E.L.

\section{PENICILLIN IN GENERAL PRACTICE}

By J. L. Hamilton-Paterson, M.D.

(New York, London, and Toronto : Staples Press Ltd. 1947. Second Edit. Pp. 105, with charts and illustrations. Price 5s. net.)

The first edition of this very useful little book was published in 1946, and so rapidly is the field of antibiotics changing its lines of development that already a second edition has appeared, bringing a variety of matters up to date.

There are some useful paragraphs on skin sensitivity and allergic reactions and their significance. Local administration by dressings and ointments and the rather newer use of finely divided sprays (areosols) are more fully discussed. The treatment of subacute bacterial endocarditis is brought up to date, and the chapter covering such miscellaneous conditions as urinary infections, the fevers, puerperal sepsis, and meningitis carries a number of new points. It is interesting to note that nowadays therapeutic concentrations of penicillin can be obtained within the eyeball, apparently without local toxic effect. The chapter on venereal diseases is short but to the point and should remind us of the limitations as well as the success of penicillin in this sphere. On the technical side, only the briefest outline of the older laboratory methods is given ; but in a work of this type more is not necessary. In that a variety of technical modifications are daily being introduced in different laboratories, this section might well have been left out altogether. There is one actual though obviously accidental omission which occurs in the table giving the sensitivity of various organisms tested in vitro, where there is no mention of the gonococcus. However, the omission in no way influences the conclusion that this little book contains a really concise and helpful review of a subject changing so rapidly. The author cannot be expected to do more than, first, carefully catalogue the facts, and then append the latest possibilities and suggestions. These tasks he has done most admirably.

F.A.K.

\section{MONOGRAPHS ON THE PROGRESS OF RESEARCH IN HOLLAND : MODERN DEVELOPMENTS OF CHEMOTHERAPY}

By E. Havinga, H. W. Julius, H. Veldstra, and K. C. Winkler

(Amsterdam : Elsevier Publishing Co., Inc.: London: Cleaver-Hume Press Ltd. 1946. Pp. $175^{\circ}$ Price 15s. net.)

No doubt most of us have imagined that under the stress of invasion and the long hard five years of German occupation the tide of medical research in Holland would have remained at low ebb throughout that long period of suffering. It is therefore with some surprise and with much admiration that readers in Great Britain will inspect this sample of the series of monographs on the progress of Dutch research work during the world war 1939-45. Modern Developments of Chemotherapy, one of a series of twelve monographs on scientific subjects, is a slim, attractive volume of 175 pages, excellent as to print and general format. It tells the story in detail of wartime research by Dutch scientists on the mechanism of the action of the sulphonamides, on investigations into the synthesis and activity of new sulphanilamide derivatives, and on pharmacological studies and therapeutic results. Extensive studies are recorded of the physico-chemical characters of the sulphonamides, especially in relation to their antagonism by $p$-aminobenzoic acid and peptone. The methods of investigation included electrometric titrations, the study of ultraviolet absorption spectra, and determinations of surface activity. The behaviour of bacterial cultures in media containing sulphonamides receives detailed and extensive consideration, following which the work of Dutch scientists on the mode of action of these compounds is fully and critically discussed.

Among the many sulphonamide compounds synthesised during the German occupation are eighteen derivatives of pyrimidine, of which six 